\title{
Dewan Redaksi \\ ( Buana Ilmu )
}

\author{
Pelindung : Dr. H. Dedi Mulyadi, SE., MM. \\ Penanggung Jawab : Ahmad Fauzi, M.Kom \\ Ketua Redaksi : Dr. Sungkono, SE., MM. \\ Sekretaris Redaksi : H. Tarpan Suparman, S.Pd., M.Pd \\ Mitra Bestari $\quad$ : Prof. Dr. H. Azhar Affandi, SE., MM \\ (Universitas Pasundan Bandung) \\ Dr. H. Puji Isyanto, SE., MM \\ (Universitas Buana Perjuangan Karawang) \\ Anggota Redaksi : : Hanny Hikmayanti H, M.Kom
}

Diterbitkan oleh Lembaga Penelitian dan Pengabdian Pada Masyarakat Universitas Buana Perjuangan Karawang

Alamat Redaksi: Jl. HS Ronggowaluyo Telukjambe Timur Karawang 41361 Telp/Fax. (0267) 8403140 website :journal.ubpkarawang.ac.id 